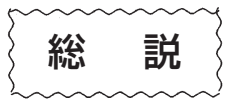

\title{
ベこ病
}

横山 博*

(2017年11月 2 日受付)

\section{Beko Disease of Cultured Fish in Japan}

\author{
Hiroshi Yokoyama* \\ The University of Tokyo, Bunkyo, Yayoi 1-1-1, Tokyo 113-8657, Japan
}

(Received November 2, 2017)

\begin{abstract}
Beko disease is derived from the concave body surface of fish infected with microsporidians in the myocytes. In this paper, several fish microsporidians including Microsporidium seriolae from Seriola spp. (S. quinqueradiata, S. dumerili and S. lalandi), Microsporidium spp. from three other cultured fish, and Heterosporis anguillarum from Japanese eel Anguilla japonica are reviewed. A shift of eel-farming method from open field ponds to house-type heating culture systems has emerged the beko disease in cultured Japanese eel. Considering the successful transmission of $H$. anguillarum to uninfected juveniles, frequent screening in eel size seems to reduce the incidence of the disease in eel farms. Previously, beko disease of yellowtail S. quinqueradiata was not been considered as a serious problem, because yellowtail juveniles infected with $M$. seriolae usually recover from the disease until the time of adult stage. However, serious condition of the disease in cultured yellowtail has recently received attention as a re-emerging disease. Unknown life-cycle of $M$. seriolae makes the control measures difficult. As diagnostic methods, microscopic examination with Uvitex 2B staining and molecular tools with PCR have been developed. Furthermore, other related microsporidians have been reported in cultured red sea bream Pagrus major, hatchery-bred spotted halibut Verasper variegatus and juvenile Pacific bluefin tuna Thunnus orientalis.
\end{abstract}

魚類のべこ病は, 各種微胞子虫類が魚類の体側筋肉に 寄生して，体幹が肉眼的に凹凸を呈する（いわゆる「べ こべこ」になる）疾病である（江草，1982）。主に淡水 魚ではウナギのべこ病, 海産魚ではブリ類のべこ病が有 名である。とくに後者は近年, 再興感染症として注目さ れており, 寄生虫の種類は異なるものの, 宿主範囲もブ リ類以外の多様な魚種に広がってきている（Table 1）。 クドア属粘液胞子虫類のように人間に害を及ぼす種類は ないが，水産業上の被害は甚大である。

従来, 微胞子虫類の生活環は, アユのグルゲア症原因 種アユグルゲアビホウシチュウ Glugea plecoglossii のよ うに，中間宿主をもたない，比較的，単純なサイクルだ と考えられてきた。しかし, サケ科魚類の武田微胞子虫 症や多くの海産微胞子虫症のように, 中間宿主を有する

東京大学大学院農学生命科学研究科

* Corresponding author

E-mail: ayokoh@mail.ecc.u-tokyo.ac.jp
と考えられるものや，まったく不明のものも多く存在す る。事実, 海外では夕イセイヨウサケ Salmo salar に寄 生する微胞子虫 Paranucleospora theridionのように, 体 表に寄生するサケジラミの体内で別の発育ステージを経 てから魚に感染するとされているものや (Nylund et al., 2010), 昆虫類に寄生する微胞子虫ではミジンコ類を中 間宿主にするものさえ知られている。以上のことを考虑 すると, 魚類に寄生する微胞子虫類の多くも生活環が未 解明であるといってよいかもしれない。

微胞子虫類は胞子の形態的特徴にそしいため, 属レべ ルの分類は胞子形成前までの形態学的な特徵に基づいて なされてきた。しかし, 透過型電子顕微鏡による微細構 造の観察は熟練を要するため, そこまでに至らない種類 は集合群として Microsporidium 属に一括され, 暫定的 に記載されている。ブリ類のべこ病原因微胞子虫 Microsporidium seriolae な゙も，そのような段階であり， 今後の研究次第では新たな属に命名される可能性がある 
Table 1. A list of microsporidians causing the beko disease in Japanese cultured fish

\begin{tabular}{llll}
\hline \multicolumn{1}{c}{ Species name } & Mean or range of spores $(\mu \mathrm{m})$ & NCBI Acc. No. & \multicolumn{1}{c}{ Host fishes in Japan } \\
\hline Heterosporis anguillarum & Macrospore: $6.7-9.0 \times 3.3-5.3$ & AF387331 & Anguilla japonica \\
& Microspore: $2.8-5.0 \times 2.0-2.9$ & & Seriola quinqueradiata, S. dumerili, S. Ialandi \\
Microsporidium seriolae & $3.34(2.9-3.7) \times 2.22(1.9-2.4)$ & AJ295322 & Pagrus major \\
Microsporidium sp. RSB & $3.47(2.9-3.9) \times 2.29(1.9-2.6)$ & AJ295323 & P \\
Microsporidium sp. SH & $3.07(2.8-3.8) \times 2.13(1.8-2.3)$ & EU871680 & Verasper variegatus \\
Microsporidium sp. PBT & $2.73(2.4-2.9) \times 1.52(1.2-1.7)$ & GU124636 & Thunnus orientalis \\
\hline
\end{tabular}

ことを理解していただきたい。

以上の理由から, 魚類寄生微胞子虫類には分類未確定 とされ，ミクロスポリジウム属として一時的に名付けら れている種類が多い。そこで, 微胞子虫胞子の内壁がキ チン質で構成されていることを利用して，キチン質に特 異的に結合するユビテックス 2B（Uvitex 2B）という蛍 光色素により染色し，蛍光顕微鏡の UV 励起光により蛍 光を発するかどうか確認することで，微胞子虫であるこ とは確認できる（Yokoyama et al., 1996）。

本総説では，いわゆる「べこ病」として有名な，ウナ ギのべこ病とブリ類のべこ病を中心に, 過去から現在ま での知見を総括する目的で執筆した。また，近年，日本 産養殖魚介類の寄生虫の標準和名目録が作成されたので （横山・長澤，2014），本総説ではなるべく寄生虫の和名 を用いて記述することにした。

\section{ウナギのべこ病}

\section{歴史}

ウナギ養殖業は黎明期の露地池養殖から現在のハウス 式加温養殖まで, 養殖方法に大きな変遷があり, それに 伴って発生する疾病も変わってきた。すなわち, 露地池 養殖で主流であった「パラコロ病」がハウス式養鰻に なってすっかり影を潜め, 代わってべこ病が台頭してき た。飼育水温が $30^{\circ} \mathrm{C}$ 以上となり「パラコロ病」原因菌の 発育限界を超えたことと, 高密度飼育により微胞子虫の 伝播が容易になったことがその要因であろう。

歴史的には，静岡県等のウナギ養殖場に扔いて本病が 大発生し, 原因体が新種の微胞子虫であると報告された ことで問題となった。しかし近年，本病は日本ですっか り終息し，少なくとも産業的被害はもたらしていない。 その原因は必ずしも明らかではないが, 台湾や中国産の 養殖ウナギの輸入増加に伴って, 国産の養殖ウナギの生 産量が減ってきたこともその一因と考えられる。90年代 までは原因微胞子虫のインビト口培養など本病の研究も 盛んであったが（Kou et al., 1995），近年では発表される 論文数も減少の一途を辿っている。

\section{病原体}

病原体はウナギイケイビホウシチュウ（Heterosporis anguillarum) である。当初, 学名はPleistophora
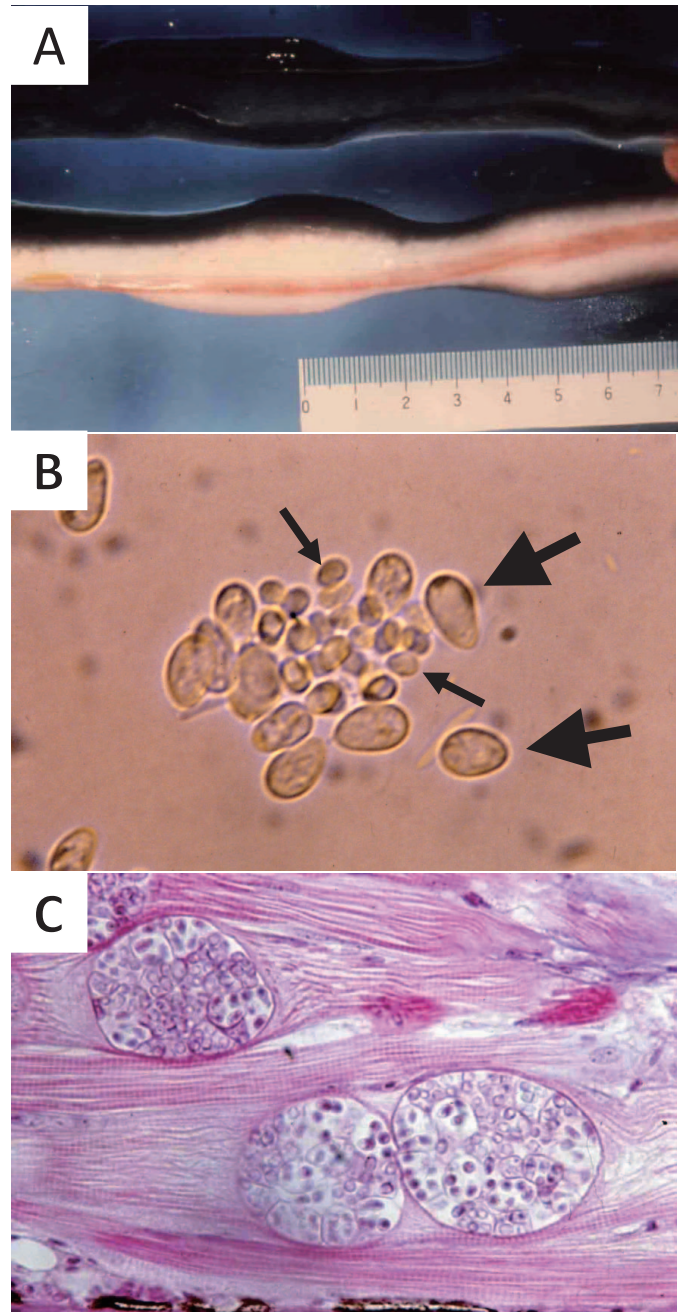

Fig. 1. Beko disease of Japanese eel Anguilla japonica. External sign (A), fresh spores of Heterosporis anguillarum (B) and pansporoblasts in the myocytes (C). Note the macrospores (large arrows) and microspores (small arrows). Photographs by H. Oka.

anguillarum と命名されたが，その後，分類の改正によ り, Heterosporis 属に転属された。なお, Heterosporis 属（イケイビホウシチュウ [異形微胞子虫］属）とは, パンスポロブラスト内に見られる寄生体の発育ステージ が同調していないことに起因する。

形態学的に, 胞子は大小 2 型あるのが特徵で, 大胞子 は棈円形で 6.7 9.0 $\times$ 3.3 5.3 $\mu \mathrm{m}$, 小胞子は米粒型で 2.8 5.0 $\times 2.0 \sim 2.9 \mu \mathrm{m}$ である（Fig. 1)。胞子に大小 2 
型ある理由は不明であるが，極管が長短 2 タイプあるこ とから，感染様式に関係しているのかもしれない。自家 感染も起こると言われているが，そのメカニズムは不明 である。

ウナギイケイビホウシチュウは，胞子を経口的または 経皮的に接種することで人為感染が成立することから， 単純な生活環を有するとされている。発育は水温に依存 し， $15^{\circ} \mathrm{C}$ ではほとんど発育せず，25ㄷ 前後では30日後 に可視大となり，30C 近くまでは高温ほど早く進む。ウ ナギの体側筋肉の細胞内に定着後, 自ら膜を形成してパ ンスポロブラストを作り，その内部で胞子形成を行う。 剖検では筋肉患部が白濁して見えることが多く，パンス ポロブラストの崩壊に伴って寄生虫由来のタンパク分解 酵素によって宿主の組織が融解することで体表が凹凸を 呈すると考えられている。

\section{診断法}

外観的に体表の凹凸を肉眼観察した後，剖検により体 側筋肉の白濁を確認する（Fig. 1)。患部から少量の組織 を取り, ウェットマウント標本により胞子の存在を検査 する。その後，塗抹標本を作製して，ユビテックス2B 染 色し, 蛍光顕微鏡（UV 励起）により胞子の輪郭が蛍光 を発するかどうか確認する。

\section{防除・予防}

魚から魚へ水平伝播することから，病魚を見つけたら 早めに排除して感染源を除去する。また共食いによる感 染も起こるので，頻繁に選別を行って魚のサイズを揃え ることも対策の一つである。実験的には，抗生物質フマ ギリンの経口投与も有効であると報告されているが（加 納ら，1982），予防的に投与せざるを得ないことと，副 作用があることから，現実的ではない。

\section{ブリ類のベこ病}

\section{歴史}

ブリ養殖の黎明期から知られていたブリ稚魚の疾病で ある。病気として報告されたのは，江草（1982）による 論文が最初である。当時はモジャコ期にのみ見られる疾 病で，成長に伴って治るために大きな産業的被害は与え なかった。しかし，90年代ごろから出荷サイズの成魚に もシストが残存していることがあり，クレームが目立つ ようになった。さらに近年では養殖場でも大量死の原因 と認識されるほど深刻な状態になっており，再興感染症 として注目を集めている。

\section{病原体}

病原体はブリキンニクビホウシチュウ Microsporidium seriolae である。胞子は米粒型で，長さ $2.9 \sim 3.7 \mu \mathrm{m}$, 幅
1.9〜2.4 $\mu \mathrm{m}$ である（Fig. 2）。近年，Kabatana 属に分類 するという論文も出ているが，本種について胞子形成前 の発育ステージを透過型電子顕微鏡により詳細に観察し た報告はない。なお，魚体から分離した胞子を未感染魚 に経口的または経皮的に接種しても人為感染が成立しな いことから，生活環は不明とされ，中間宿主の介在が推 測されている。

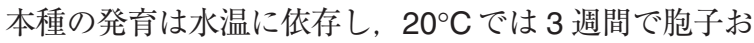
よびシストを形成する。その後, シストが崩壊し, マク ロファージ等に貪食されて体内の各所に運ばれたり，シ スト形成局所では宿主の線維組織に包囲化されたりする。 さらにメラニン沈着を起こして黒化し, 萎縮していき, 最終的には肉眼的に識別できないほど矮小化して治癒す る。

魚を感染場所に曝露する実験により，魚への感染期は 5〜 7月，とくに 6 月にピークがあり，8月になると終 息すると考えられてきた（Sano et al., 1998）。しかし， 近年では秋季にも感染することが分かってきている。最

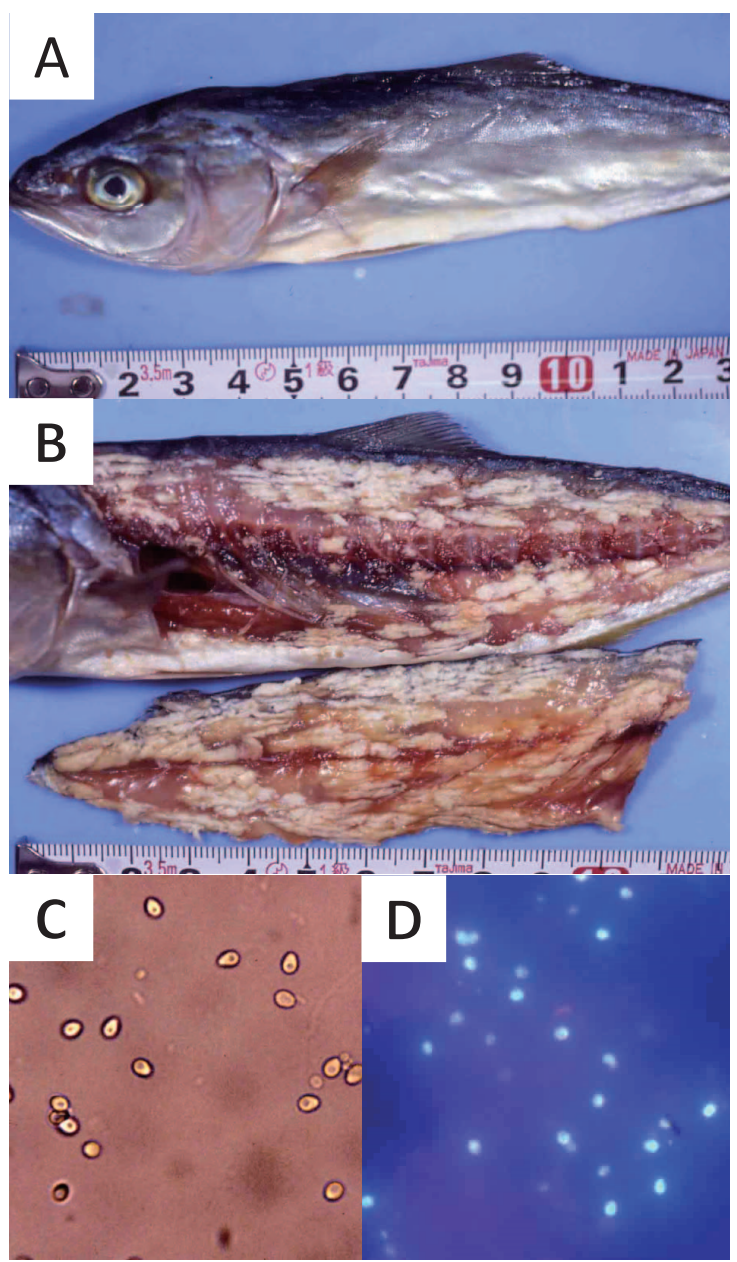

Fig. 2. Beko disease of yellowtail Seriola quinqueradiata. External appearance $(A)$, internal sign $(B)$, fresh spores (C) and Uvitex 2B-stained spores (D) of Microsporidium seriolae. 
近, 環境水中の微胞子虫類の遺伝子量をリアルタイム PCR 法により定量化する試みもなされており，発育の季 節的消長については，さらなる検討が必要である。

\section{診断法}

外観で凹凸を観察した後，解剖して白いシストを確認 する (Fig. 2)。典型的には，シストは木屑状に見られる。 シストの一部を少量の水分とともにスライドグラスに乗 せ，カバーグラスをかけて光学顕微鏡により胞子の形態 を調べる。その後，塗抹標本を作製して，ユビテックス 2B 染色し, 蛍光顕微鏡 (UV 励起) により胞子が蛍光を 発するかどうか確認する（Fig. 2)。遺伝子レベルで確認 するPCR 法も開発されている（Bell et al., 1999）。

\section{防除・予防法}

陸上飼育期間中に用水を砂ろ過することで感染防除で きる（Sano et al., 1998）。砂ろ過の目合いはブリキンニ クビホウシチュウの胞子よりも粗いはずであるが，なぜ 防除できるのかは明らかでない。中間宿主を摂食して感 染するのであれば，それをトラップするのかもしれない し, 砂ろ過槽に定着した様々な細菌叢が放出する化学物 質により殺虫されるのかもしれない。

微胞子虫類の感染には場所と時期が限られているもの が知られているので, 疫学調査により感染しにくい場所 および時期を特定して，そこを回避する（または陸上で 飼育する）などの対策が考えられる。

魚体のサイズと寄生強度の関係については, $100 \mathrm{~g}$ 以 上の稚魚には感染するものの寄生強度は低いことが報告 されている (Yokoyama et al., 2011)。大型のモジャコを 導入することで完全に防除することはできないものの,

1 個体あたりのシスト数が 5 個以内であれば, 出荷時に はほとんど治癒すると考えられる。

魚体内に侵入した発育ステージの駆虫薬として，アル ベンダゾールの経口投与が有効である。最近, 発症前の 予防的な投薬により（実際には，PCR 法などにより魚体 内への初期侵入を確認してから投与する）でほぼ完全に 防除できることが特許出願として公開された（林兼産業 株式会社・国立大学法人東京大学・マルハニチロ株式会 社. 魚介類の微胞子虫の防除用組成物及びそれを用いた 魚介類の微胞子虫の防除方法. 特願2017-047531)。今 後，すべての養殖業者が使用できるように，水産用医薬 品として承認する研究を進める必要がある。

\section{その他の魚種のべこ病}

\section{背景・病原体}

ここ数年, ブリ類以外の養殖魚でもべこ病が発生し, 暫定的に新種として報告されている（江草ら，1988； Yokoyama et al., 2008; Zhang et al., 2010)。発表年順に
は, マダイの Microsporidium sp. RSB，ホシガレイの Microsporidium sp. SH，クロマグロの Microsporidium sp. PBT がある（学名の後の RSB, SH, PBT は, 各宿主 魚の英名の略称)。いずれも木屑状のシス卜を作る点でブ リキンニクビホウシチュウと似ているが，形態学的，分 子生物学的にはすべて別種と考えられている。それぞれ， マダイビホウシチュウ, ホシガレイビホウシチュウ, マ グロビホウシチュウという和名が提唱された（横山・長 澤，2014）。

\section{診断法}

他のべこ病原因微胞子虫類と同様，剖検により木首状 のシストを確認した後，シストの一部のウェットマウン ト標本により胞子の形態を検査する（Fig. 3）。胞子の形

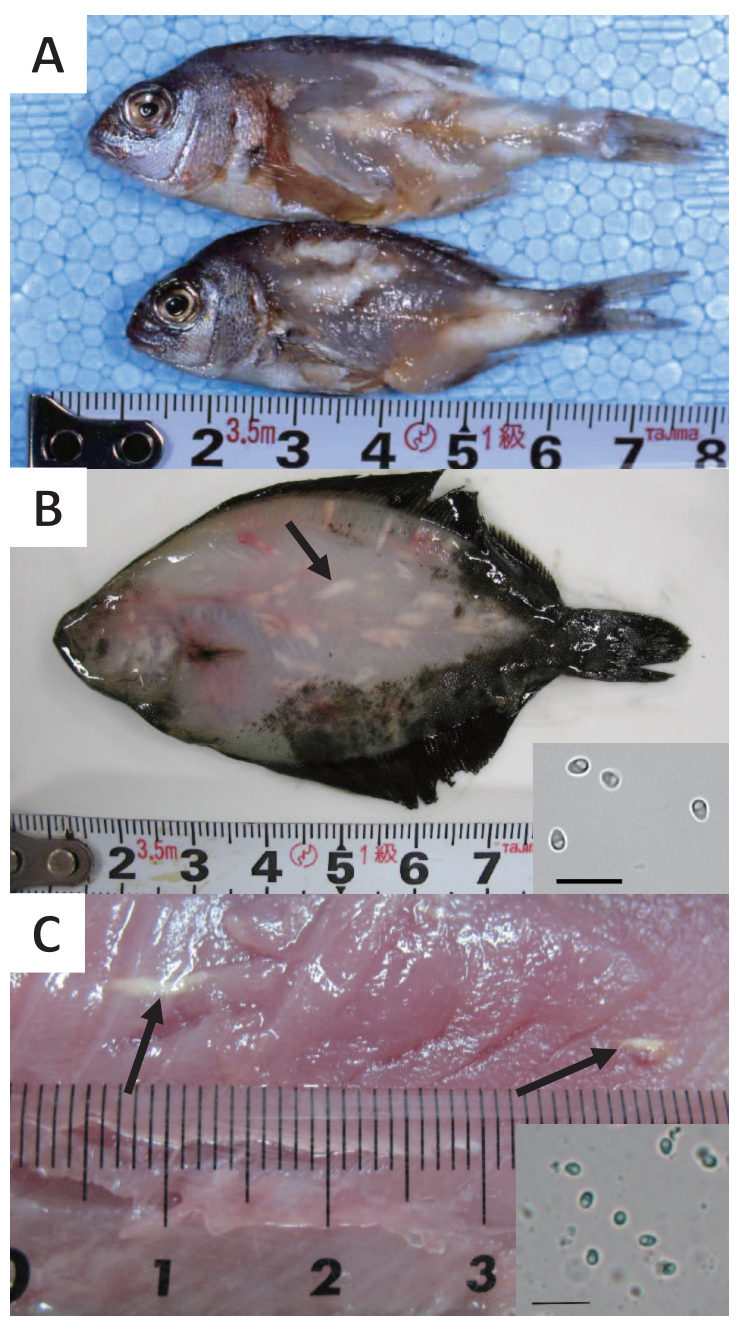

Fig. 3. Beko diseases of three other fish species. A: affected red sea bream Pagrus major. B: affected spotted halibut Verasper variegatus and fresh spores (inset). Arrow shows a cyst of Microsporidium sp. SH. Scale bar is $10 \mu \mathrm{m}$. Images are cited from Yokoyama et al. (2008). C: affected Pacific bluefin tuna Thunnus orientalis and fresh spores (inset). Arrows show cysts of Microsporidium sp. PBT. Scale bar is $10 \mu \mathrm{m}$. 
態とサイズは，マダイビホウシチュウは茄子型で長さが 2.9〜3.9 $\mu \mathrm{m}$, 幅が 1.9〜2.6 $\mu \mathrm{m}$, ホシガレイビホウシ チュウは卵型で長さ 2.8〜 3.8 $\mu \mathrm{m}$, 幅 $1.8 \sim 2.3 \mu \mathrm{m}$, マグ ロビホウシチュウは米粒型で長さ 2.4 2.9 $\mu \mathrm{m}$, 幅 1.2 $1.7 \mu \mathrm{m}$ と，それぞれ微妙に異なっている（Table 1）。最 終的に塗抹標本を作製して，ユビテックス $2 \mathrm{~B}$ 染色を施 し，蛍光顕微鏡（UV 励起）により蛍光を発するかどう か確認する。

なお，各種を識別する PCR 法は開発されていないが, いずれも $16 \mathrm{~S}$ rDNA の塩基配列が登録されているので, シーケンスすることにより遺伝的に同定することも可能 である。

\section{防除対策}

基本的には，ブリのべこ病と同様の対策が有効と思わ れる。養殖クロマグロでは, 経時的にシスト数が減少す る傾向も見られており, 出荷時にはほぼ完全に消失する と考えられる。将来的には，アルベンダゾールなどの経 口投与が現実的であろう。

\section{文献}

Bell, A. S., H. Yokoyama, T. Aoki, M. Takahashi and K. Maruyama (1999): Single and nested polymerase chain reaction assays for the detection of Microsporidium seriolae (Microspora), the causative agent of 'Beko' disease in yellowtail Seriola quinqueradiata. Dis. Aquat. Organ., 37, $127-134$

江草周三 (1982)：ブリ幼魚のベコ病の病原微胞子虫について. 魚病研究, 16, 187-192.

江草周三・畑井喜司雄・藤巻由紀夫（1988）：マダイ稚魚べこ 病の病原微胞子虫 Microsporidium sp. について. 魚病研究, 23, 263-267.

加納照正・岡内哲夫・福井晴朗（1982）：ウナギのプリストホ ラ症に関する研究－II. フマジリンの投薬方法と効果につ いて. 魚病研究, 17, 107-114.

Kou, G.-H., C.-H. Wang, H.-W. Hung, Y.-S. Jang, C.-M. Chou and C.-F. Lo (1995): A cell line (EP-1 cell line) derived from "Beko disease" affected Japanese eel elver (Anguilla japonica) persistently infected with Pleistophora anguilla- rum. Aquaculture, 132, 161-173.

Nylund, S., A. Nylund, K. Watanabe, C. E. Arnesen and E. Karlsbakk (2010): Paranucleospora theridion n. gen., $\mathrm{n}$. sp. (Microsporidia, Enterocytozoonidae) with a life cycle in the salmon louse (Lepeophtheirus salmonis, Copepoda) and Atlantic salmon (Salmo salar). J. Eukaryot. Microbiol., 57, 95-114.

Sano, M., J. Sato and H. Yokoyama (1998): Occurrence of beko disease caused by Microsporidium seriolae (Microspora) in hatchery-reared juvenile yellowtail. Fish Pathol., 33, $11-16$.

Yokoyama, H., J.-H. Kim, J. Sato, M. Sano and K. Hirano (1996): Fluorochrome Uvitex 2B stain for detection of the microsporidian causing beko disease of yellowtail and goldstriped amberjack juveniles. Fish Pathol., 31, 99-104.

Yokoyama, H., F. Yokoyama, J.-Y. Zhang, K. Tsuruoka and K. Ogawa (2008): Microsporidian infection in the trunk muscle of hatchery-bred juvenile spotted halibut Verasper variegatus. Fish Pathol., 43, 137-143.

Yokoyama, H., D. Ayado, J. Miyahara, K. Matsukura, I. Takami, F. Yokoyama and K. Ogawa (2011): Infection dynamics of Microsporidium seriolae (Microspora) causing the beko disease of Seriola spp. Fish Pathol., 46, 51-58.

横山 博 - 長澤和也 (2014) : 養殖魚介類の寄生虫の標準和名目 録. 生物圈科学, 53, 73-97.

Zhang, J., F. Meng, H. Yokoyama, J. Miyahara, I. Takami and K. Ogawa (2010): Myxosporean and microsporidian infections in cultured Pacific bluefin tuna Thunnus orientalis in Japan. Fish. Sci., 76, 981-990.

\section{付 録}

Uvitex 2B 染色のプロトコル

1）スタンプまたは塗抹標本をメタノール原液で固定 する。

2）リン酸緩衝液に $1 \%$ の濃度で溶解した Uvitex2B 液 を載せ，10分間，染色する。

3）蒸留水で軽く洗浄後, $0.5 \%$ エバンスブルー液で30 秒間，対照染色する。

4) 洗浄, 風乾後, 蛍光顕微鏡 (UV励起) で観察する。 *組織切片標本の場合は, 通常の H \& E 染色の直前に,

上記2）の処理を入れる。 